\title{
Total Phenolic Contents and Antioxidant Activity in Oxidized Leaves of Mate (Ilex paraguariensis St. Hil)
}

\author{
Rochele Fernanda Molin ${ }^{1}$, Nessana Dartora ${ }^{2}$, Ana Cláudia Piovezan Borges ${ }^{1}$, Itamar Luís \\ Gonçalves $^{3}$, Marco Di Luccio ${ }^{1}$ and Alice Teresa Valduga ${ }^{1 *}$ \\ ${ }^{I}$ Programa de Pós-graduação em Ecologia; Universidade Regional Integrada do Alto Uruguai e das Missões; Erechim - \\ $R S$ - Brasil. ${ }^{2}$ Programa de Pós-graduação em Bioquímica; Universidade Federal do Paraná; Curitiba - PR - Brasil. \\ ${ }^{3}$ Departamento de Ciências da Saúde; Universidade Regional Integrada do Alto Uruguai e das Missões; Erechim -RS - \\ Brasil.
}

\begin{abstract}
Ilex paraguariensis is a native species to South America. Its economic importance is in the use of its leaves and twigs in the processing of a product popularly known as "chimarrão". The aim of this study was to evaluate the correlations between some physico-chemical process parameters in the oxidation of I. paraguariensis leaves oxidation. The leaves of Maté with age 1.0, 6.5 and 12.0 months were subjected to an oxidation process for $3 h$ under different relative humidity conditions $(80,90$ and $99 \%)$ at $26^{\circ} \mathrm{C}$. The extracts were evaluated using the experimental design techniques to maximize the oxidation conditions for the total polyphenols, antioxidant capacity, water activity and color. The condition of $90 \%$ humidity and leaf age 6.5 months resulted in lower lightness and yellow color of the product. Green color was not significantly influenced by the studied parameters. The highest levels of total phenols and antioxidant potential were found when the leaf age was one month and humidity was 90\%. Thus, it could be concluded that the air humidity of the chamber and leaf age influenced the oxidation process of the leaves of Maté as well as the antioxidant capacity of the extract obtained.
\end{abstract}

Key words: yerba-mate; oxidative process; physicochemical parameters; antioxidant activity

\section{INTRODUCTION}

I. paraguariensis (known as "Maté" outside Brazil) consists of a native species to South America (Brazil, Argentina, Paraguay and Uruguay), belonging to the family aquifoliacea. Its economic importance is in the use of its leaves and twigs to prepare a product widely used by the population of these countries, popularly known as "chimarrão" (Bastos et al. 2006). Maté is able to stimulate the central nervous system due to its content of methylxanthine such as caffeine, and presents in its composition acidic phenolic compounds with antioxidant activity (Pomilio et al. 2002; Zaporozhets et al. 2004; Bravo et al.
2007; Deladino et al. 2007). Studies have revealed that the Maté has significant antioxidant properties (Colpo et al. 2007; Filip et al. 2007; Lanzetti et al. 2008; Miranda et al. 2008). These characteristics were also found in studies conducted in New Mexico with 30 medicinal plants, where $I$. paraguariensis had the highest antioxidant activity among the tested plants (Vanderjagt et al. 2002), and also, when compared with green and black teas (Lunceford and Guigluicci 2005).

The Camellia sinensis teas are the most popular beverages worldwide, but differently from Maté, C. sinsensis is prepared via oxidative processes, to yield white, oolong, and black teas. Black tea is prepared after intensive oxidation, promoting

*Author for correspondence: valice@uricer.edu.br 
alteration in the flavor and taste, which is very appreciated by the consumers (Obanda et al. 2001; Muthumani and Kumar 2007). The oxidation process is not yet used for Maté leaves, but could be an alternative to prepare the beverages resembling black tea.

Besides the antioxidant properties, Maté has hypocholesterolemic effect due to the reduction of oxidation of low density lipoproteins (LDL), minimizing the formation of atheroma, characteristic attributed to the phenolic constituents in the leaves (Bracesco et al. 2003; Menini et al. 2007). The concentration of polyphenols in the Maté has a strong correlation with the antioxidant capacity of this product (Chandra and Mejia 2004). Due to the ability to prevent the oxidation of liposomes, the extracts of I. paraguariensis is considered to have two times the antioxidant activity compared with red wine (Filip et al. 2001).

The phenolic compounds are the major constituents present in a large number of plant species, which have antioxidant activities (Saldanha 2005; Mejia et al. 2010). Thus, it is important to assess the levels of these compounds in the extracts from the oxidized leaves of Maté. In this context, this work aimed at studying the effect of some conditions of oxidation on the antioxidant activity, content of phenolic compounds and color of the final product.

\section{MATERIAL AND METHODS}

\section{Plant material and sample preparation}

Leaves (with 1.0, 6.5 and 12.0 months old) from $I$. paraguariensis were collected in the morning and were submitted to dehydration for $2 \mathrm{~h}$ using an oven with air circulation at $30^{\circ} \mathrm{C}$. The leaves were manually rolled (placed in a cotton cloth and pressed) at room temperature $\left(25^{\circ} \mathrm{C}\right)$ for $5 \mathrm{~min}$, then were transferred to aluminum trays and placed in a climatic chamber at $26^{\circ} \mathrm{C}$. Thereafter, the leaves were dried in a fixed bed dryer with hot air at $70^{\circ} \mathrm{C}$ for $120 \mathrm{~min}$. Dried leaves were crushed in a blender and sorted in a sieve $(2.36 \mathrm{~mm})$. Sieved fraction was used for the analysis under the conditions described in an experimental design.

\section{Experimental design}

The experimental conditions of oxidation were defined by a complete factorial design $2^{2}$ (Molin et al. 2011) as shown in Table 1. The study was aimed at maximizing the oxidation of leaves of
Maté containing $50 \%$ of moisture in function of the age of the leaves and humidity of the incubation chamber.

Table 1 - Values of central composite design $2^{2}$ for the development of the oxidation process of leaves of mate.

\begin{tabular}{lllll}
\hline Variables & & $\mathbf{- 1}$ & $\mathbf{0}$ & $\mathbf{1}$ \\
\hline Relative humidity (\%) & $\mathrm{X}_{1}$ & 80 & 90 & 99 \\
$\begin{array}{l}\text { Age of the leaves } \\
\text { (months) }\end{array}$ & $\mathrm{X}_{2}$ & 1 & 6.5 & 12 \\
\hline
\end{tabular}

\section{Preparation of the extracts}

The ground leaves $(5.0 \mathrm{~g})$ of each sample were submitted to cold extraction with a mixture of water and acetone (1:1, v/v) (Turkmen et al. 2006). The samples were placed on filter paper and soaked in solvent for $24 \mathrm{~h}$ (Saldanha 2005). The volume of extract was adjusted to $100 \mathrm{~mL}$ and stored in amber flasks at $-18^{\circ} \mathrm{C}$.

\section{Water activity (aw)}

The determination of water activity was carried out with $1.0 \mathrm{~g}$ of sample, in triplicates, in an Aqualab system (Decagon, Model CX-2) at $25^{\circ} \mathrm{C}$. The equipment was previously calibrated with a sodium chloride solution with $\mathrm{a}_{\mathrm{w}} 0.882$, following the recommendations of the equipment's operation manual.

\section{Color}

Instrumental color was determined using a colorimeter (Minolta CR400), with light source D65, expressing the results in the CIELAB color scale $\left(\mathrm{L}^{*} \mathrm{a} * \mathrm{~b} *\right)$. Equipment calibration was carried out using a standard white plaque. Before measurements, particle size of samples was standardized (less than $2.36 \mathrm{~mm}$ ), and samples were placed in a Petri dish (9-cm diameter) using the amount of sample necessary to completely cover the bottom of the dish. Measurements were carried out in triplicates.

\section{Determination of total phenolic contents}

Total soluble phenolic compounds in the methanolic extracts were measured according to method previously described and expressed as pyrocatechol acid equivalents (Kolakowska and Frankel 2000). A sample of $0.25 \mathrm{~mL}$ was diluted to a final volume of $2.0 \mathrm{~mL}$ with distilled water. Then, it was mixed with $0.3 \mathrm{~mL}$ of a saturated sodium carbonate $\left(\mathrm{Na}_{2} \mathrm{CO}_{3}\right)$ solution and $0.1 \mathrm{~mL}$ of $1 \mathrm{~N}$ Folin-Ciocalteu's phenol reagent. The 
mixture was placed for $1 \mathrm{~h}$ at room temperature in a dark environment. The absorbance was measured at $725 \mathrm{~nm}$ against the blank. The total soluble phenolic compounds radical was calculated using a calibration curve with pyrocathecol. The results were expressed in $\mathrm{mg}$ of pyrocathecol per $\mathrm{g}$ of dry sample.

Antioxidant capacity - DPPH radicalscavenging activity

The free radical scavenging activities of extracts were measured by using 1,1- diphenyl-2-picrylhydrazyl (DPPH) (Brand-Willians et al. 1995). For this, $750 \mu \mathrm{L}$ of each extract at concentration of $150 \mu \mathrm{g} \cdot \mathrm{mL}^{-1}$ were added to $1.5 \mathrm{~mL}$ of $\mathrm{DPPH}$ solution $\left(0.1 \mathrm{mmol} \cdot \mathrm{L}^{-1}\right)$. The mixture was vigorously shaken and the absorbance was measured at $515 \mathrm{~nm}$ at 1,10 and $20 \mathrm{~min}$. The ability to scavenge the DPPH radical was calculated using the expression: DPPH scavenging effect $\left.(\%)=100 \cdot\left[\left(\mathrm{A}_{0}-\mathrm{A}_{1}\right) / \mathrm{A}_{0}\right)\right]$, where $\mathrm{A}_{0}$ was the absorbance of the control reaction and $\mathrm{A}_{1}$ the absorbance in the presence of the sample.

\section{RESULTS AND DISCUSSION}

Effects of variables on water activity $\left(a_{w}\right)$

Table 2 shows the actual and coded values of the $2^{2}$ experimental design and responses in terms of water activities of Maté leaves subjected to oxidation at 0 (no oxidation) and $6 \mathrm{~h}$. The humidity of the chamber significantly influenced the $a_{\mathrm{w}}$. The analysis of variance yielded a high regression coefficient $(0.86)$ and calculated $\mathrm{F}$ (25.05) was higher than listed F (3.1), validating an empirical model $(p<0.05)$ for $a_{w}$, which allowed the construction of response surface shown in Figure 1. The relative humidity of chamber showed a strong influence on the $\mathrm{a}_{\mathrm{w}}$. The leaf age did not exert considerable influence on the $a_{w}$, although mature leaves had higher $a_{w}$ in these conditions.

Effects of variables on instrumental color $\left(L^{*}\right.$ $\left.\mathbf{b}^{*} \mathbf{a}^{*}\right)$

Color parameter $L^{*}$

Table 3 shows the values for parameter $\mathrm{L}^{*}$ at 0 and $6 \mathrm{~h}$ of oxidation. The parameter $\mathrm{L}^{*}$ represents the lightness of the sample, in a scale from 0 (black) to 100 (white). The analysis of variance yielded a calculated $F(6.63)$ higher than the listed $\mathrm{F}$ (3.0), thus validating an empirical model ( $\mathrm{p}$
$<0.05)$ for color parameter $\mathrm{L} *$. The model was used to plot the response surface shown in Figure 2-A. Younger leaves showed brightness index lower, when submitted to oxidation. This behavior could be due to more intense enzymatic activity. The lowest lightness was obtained at $90 \%$ humidity and leaf age as 6.5 months.

Table 2 - Matrix of the $2^{2}$ experimental design (real and coded values) with the response of $\mathrm{a}_{\mathrm{W}}$ at 0 and $6 \mathrm{~h}$ of oxidation.

\begin{tabular}{lcccc}
\hline \multirow{2}{*}{ Run } & \multicolumn{2}{c}{ Factors } & \multicolumn{2}{c}{$\mathbf{a}_{\mathbf{W}}$} \\
\cline { 2 - 5 } & $\mathbf{X}_{\mathbf{1}}$ & $\mathbf{X}_{\mathbf{2}}$ & $\mathbf{0 h}$ & $\mathbf{6 h}$ \\
\hline 1 & $-1(80)$ & $1(12)$ & 0.980 & 0.981 \\
2 & $1(99)$ & $1(12)$ & 0.850 & 0.932 \\
3 & $0(90)$ & $1(12)$ & 0.932 & 0.985 \\
4 & $-1(80)$ & $-1(1)$ & 0.981 & 0.957 \\
5 & $1(99)$ & $-1(1)$ & 0.983 & 0.942 \\
6 & $0(90)$ & $-1(1)$ & 0.941 & 0.990 \\
7 & $1(99)$ & $0(6.5)$ & 0.932 & 0.946 \\
8 & $-1(80)$ & $0(6.5)$ & 0.982 & 0.987 \\
9 & $0(90)$ & $0(6.5)$ & 0.932 & 0.995 \\
10 & $0(90)$ & $0(6.5)$ & 0.941 & 0.990 \\
11 & $0(90)$ & $0(6.5)$ & 0.946 & 0.982 \\
\hline
\end{tabular}

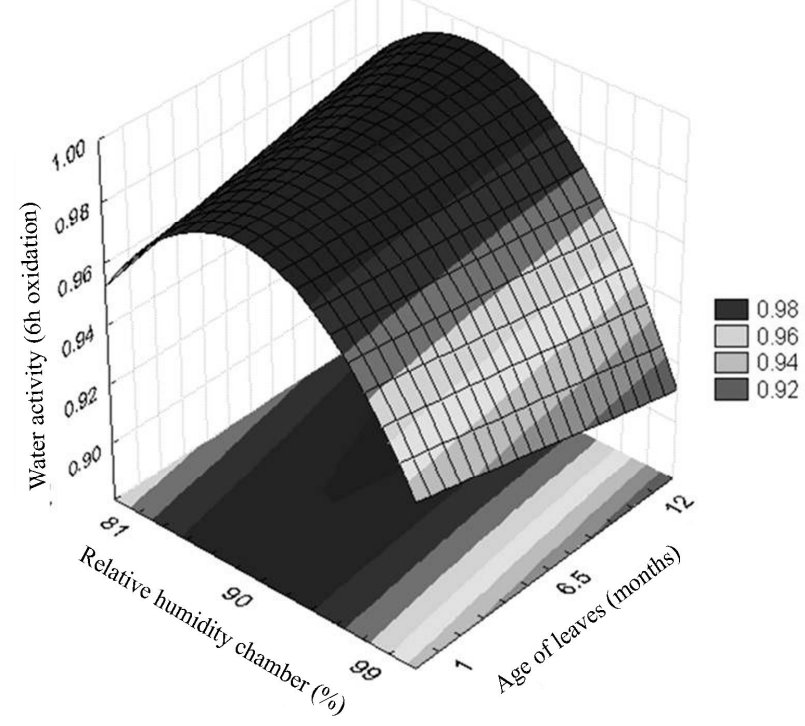

Figure 1 - Response surface for $\mathrm{a}_{\mathrm{w}}$ as a function of humidity of the chamber and leaf age after $6 \mathrm{~h}$ of incubation.

Table 3 - Matrix of the $2^{2}$ experimental design (real and coded values) with the response color parameter $\mathrm{L}^{*}$ at 0 and $6 \mathrm{~h}$ of oxidation. 


\begin{tabular}{lcccc}
\hline \multirow{2}{*}{ Run } & Factors & \multicolumn{3}{c}{ Color L* } \\
\cline { 2 - 5 } & $\mathbf{X}_{\mathbf{1}}$ & $\mathbf{X}_{\mathbf{2}}$ & $\mathbf{0 ~ h}$ & $\mathbf{6 ~ h}$ \\
\hline 1 & $-1(80)$ & $1(12)$ & 19.28 & 21.88 \\
2 & $1(99)$ & $1(12)$ & 19.91 & 20.66 \\
3 & $0(90)$ & $1(12)$ & 14.31 & 19.10 \\
4 & $-1(80)$ & $-1(1)$ & 17.04 & 20.05 \\
5 & $1(99)$ & $-1(1)$ & 18.90 & 19.70 \\
6 & $0(90)$ & $-1(1)$ & 17.98 & 18.00 \\
7 & $1(99)$ & $0(6.5)$ & 20.46 & 18.04 \\
8 & $-1(80)$ & $0(6.5)$ & 16.43 & 18.24 \\
9 & $0(90)$ & $0(6.5)$ & 15.10 & 18.21 \\
10 & $0(90)$ & $0(6.5)$ & 17.98 & 18.01 \\
11 & $0(90)$ & $0(6.5)$ & 18.76 & 18.80 \\
\hline
\end{tabular}

\section{Color parameter $\mathbf{a}^{*}$}

The studied factors did not statistically $(\mathrm{p}<0.05)$ influence the color parameter $\mathrm{a}^{*}$.

\section{Color parameter $\mathbf{b}^{*}$}

The color parameter $b^{*}$ was significantly influenced by the studied factors, which suggested a tendency for yellowing in the samples (Table 4). The analysis of variance yielded a correlation coefficient of 0.80 , and the calculated F (9.31), which was higher than the tabulated $F(3.0)$, resulting in the validation of an empirical coded model. The model was used to plot the response

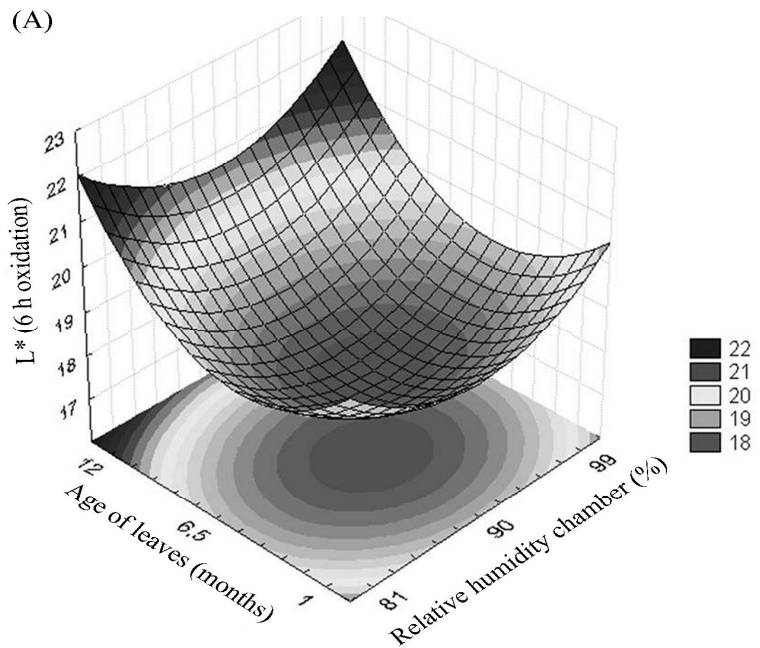

surface depicted in Figure 2-B. The increase in relative humidity resulted an increase in the color parameter $b^{*}$ only for the young leaves. This behavior was possibly due to the loss of chlorophyll present in the sample. When the mature leaves (12 months) were subjected to different incubation humidity (80\%), the effect of green color degradation was not observed.

Table 4 - Matrix of the $2^{2}$ experimental design (real and coded values) with the responses color parameter $b^{*}$ at 0 and $3 \mathrm{~h}$ of oxidation.

\begin{tabular}{lcccc}
\hline \multirow{2}{*}{ Run } & Factors & \multicolumn{3}{c}{ Color b* } \\
\cline { 2 - 5 } & $\mathbf{X}_{\mathbf{1}}$ & $\mathbf{X}_{\mathbf{2}}$ & $\mathbf{0 ~ h}$ & $\mathbf{3 ~ h}$ \\
\hline 1 & $-1(80)$ & $1(12)$ & 8.06 & 8.92 \\
2 & $1(99)$ & $1(12)$ & 7.24 & 8.29 \\
3 & $0(90)$ & $1(12)$ & 9.12 & 8.30 \\
4 & $-1(80)$ & $-1(1)$ & 7.81 & 8.14 \\
5 & $1(99)$ & $-1(1)$ & 8.28 & 10.08 \\
6 & $0(90)$ & $-1(1)$ & 7.86 & 9.37 \\
7 & $1(99)$ & $0(6.5)$ & 9.20 & 10.22 \\
8 & $-1(80)$ & $0(6.5)$ & 6.87 & 8.92 \\
9 & $0(90)$ & $0(6.5)$ & 8.16 & 9.83 \\
10 & $0(90)$ & $0(6.5)$ & 7.86 & 9.37 \\
11 & $0(90)$ & $0(6.5)$ & 8.35 & 9.24 \\
\hline
\end{tabular}

(B)

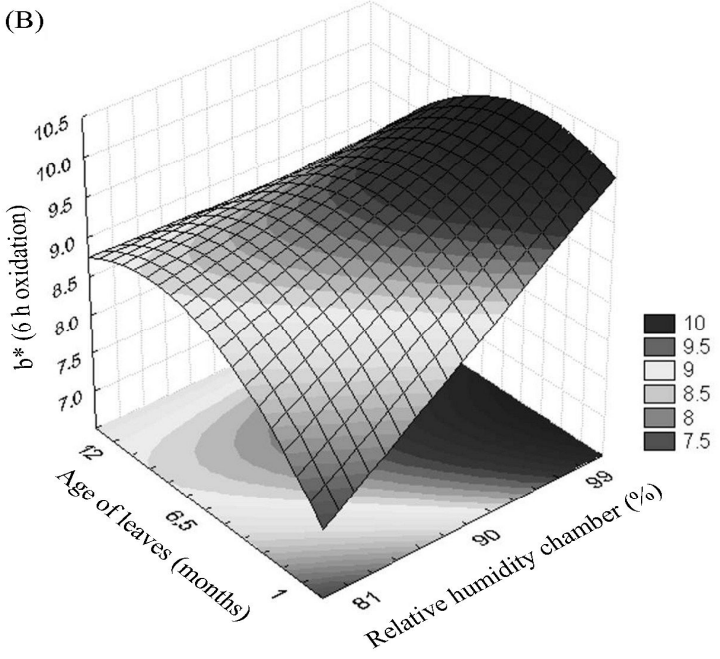

Figure 2 - Response surface to color: parameter $\mathrm{L}^{*}$ as a function of humidity of the chamber and leaf age after $6 \mathrm{~h}$ of incubation (A), and parameter $\mathrm{b}^{*}$ as a function of humidity of the chamber and leaf age after $3 \mathrm{~h}$ of incubation (B).

\section{Total phenolic contents}

Table 5 presents the concentrations of phenolic compounds after $3 \mathrm{~h}$ of oxidation in the leaves of Maté. The total phenolic contents in the oxidized
Maté ranged from $4.95 \mathrm{mg} \cdot \mathrm{g}^{-1}$ in mature leaves (12 months) to $10.0 \mathrm{mg} \cdot \mathrm{g}^{-1}$ in young leaves (1 month) under the same conditions of humidity of the chamber (Table 5). 
Table 5 - Matrix of $2^{2}$ experimental designs (real and coded values) with the response of total phenolic contents in $3 \mathrm{~h}$ of oxidation. Values expressed in mean \pm standard deviation.

\begin{tabular}{lccc}
\hline Run & $\mathbf{X}_{\mathbf{1}}$ & $\mathbf{X}_{\mathbf{2}}$ & $\begin{array}{c}\text { Phenolic } \\
\text { contents mg.g-1 }\end{array}$ \\
\hline 1 & $-1(80)$ & $1(12)$ & $7.22 \pm 0.47$ \\
2 & $1(99)$ & $1(12)$ & $7.51 \pm 0.50$ \\
3 & $0(90)$ & $1(12)$ & $4.95 \pm 0.25$ \\
4 & $-1(80)$ & $-1(1)$ & $7.87 \pm 0.57$ \\
5 & $1(99)$ & $-1(1)$ & $6.65 \pm 0.45$ \\
6 & $0(90)$ & $-1(1)$ & $10.00 \pm 0.78$ \\
7 & $1(99)$ & $0(6,5)$ & $9.03 \pm 0.79$ \\
8 & $-1(80)$ & $0(6,5)$ & $6.52 \pm 0.49$ \\
9 & $0(90)$ & $0(6,5)$ & $6.24 \pm 0.35$ \\
10 & $0(90)$ & $0(6,5)$ & $6.28 \pm 0.30$ \\
11 & $0(90)$ & $0(6,5)$ & $6.27 \pm 0.31$ \\
\hline
\end{tabular}

In the oxidation of black tea, the polyphenol content increased with the time of oxidation, with the highest conversion found in the early hour of the process and showing decreased polyphenoloxidase activity with incubation time (Muthumani and Kumar 2007).

Figure 3 shows the Pareto chart of the effects of the studied variables on the polyphenol content of the leaves of Maté oxidation. Evidently the humidity of the chamber showed a significant negative effect $(\mathrm{p}<0.05)$ on the response, i.e., the concentrations of polyphenols increased when the humidity of the chamber decreased. The phenolic properties compounds found in the ethanol extracts of herbal medicines commonly consumed in the southwestern region of Paraná ranged from 15 to $56 \mathrm{mg} \mathrm{GAE} \cdot \mathrm{g}^{-1}$ of dry leaf. The largest amount of phenolic compounds per gram of dry extract (> $55 \mathrm{mg} \mathrm{GAE} \cdot \mathrm{g}^{-1}$ ) was detected in the extracts of I. paraguariensis and Plantago spp (Assolini et al. 2006).

The stability of phenolic compounds during the dehydration and extraction is affected by the chemical and enzymatic degradation and volatization of the compounds. However, the thermal decomposition has been considered as the main cause of reducing the content of phenols. In thermal decomposition, phenols react with other components, preventing their extraction (Moure et al. 2001). The temperature during the extraction can affect the bioactive compounds in different ways. The total phenolic content decreases with increasing the temperature (Conde et al. 1998). In this study, the temperature of extraction was set at $40^{\circ} \mathrm{C}$. Some factors influence the production, quality and quantity of the active plants, including the temperature, which mostly varies between 40$60^{\circ} \mathrm{C}$ (Melo et al. 2004). The amount of extractable phenols in Maté has a strong correlation with the antioxidant capacity, but the amount of extracted compounds is affected by the method of extraction and by the solvent (water or organic solvent) (Chandra and Mejia 2004).

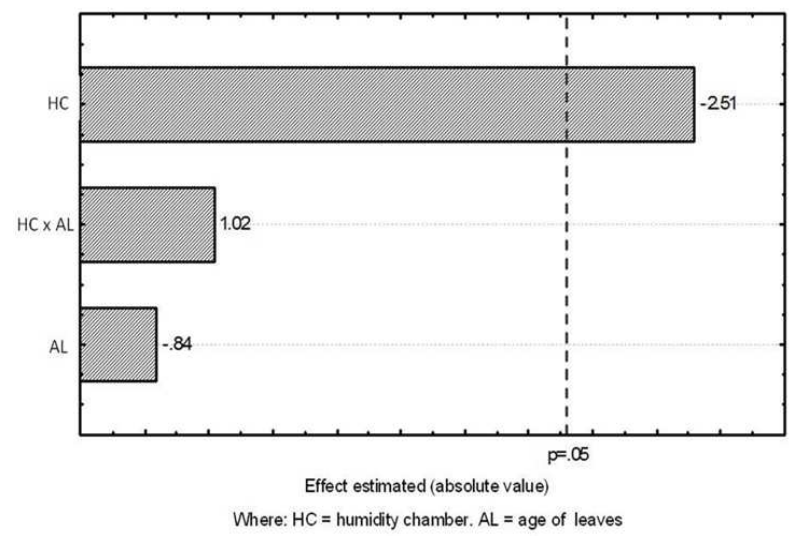

Figure 3 - Pareto chart showing the effect of relative humidity and age of the leaf on the total polyphenols after $3 \mathrm{~h}$ of incubation. $\mathrm{HC}=$ humidity of chamber (\%); $\mathrm{AL}=$ Age of leaves (months).

\section{Antioxidant capacity}

Table 6 shows the matrix of the factorial design $2^{2}$ with the actual and coded values, and antioxidant activity. The data were analyzed with a significance level of $5 \%$.

The highest antioxidant potential of the leaves of Maté was $108.57 \%$, which was found after $10 \mathrm{~min}$ (test 6), followed by the leaves subjected to conditions of test 2, which resulted in 93.16 and $94.66 \%$, respectively for 1 and $20 \mathrm{~min}$. In other studies, the aqueous extract of Maté ( $I$. paraguariensis) and green tea ( $C$. sinensis) showed antioxidant capacity higher than $89 \%$, determined by the DPPH method (Bastos et al. 2007). In this context, the proposed treatments in this study were interesting to enhance the antioxidant capacity of oxidized Maté extract.

Figure 4 shows the Pareto chart of effects of the processing variables on the antioxidant capacity of the leaves of Maté. The age of the leaf and also the humidity of the incubation chamber showed significant positive effects on the antioxidant capacity of the extract. Likewise, the interaction between the moisture of the chamber and leaf age had a significant positive effect at the level of 
confidence $\mathrm{p}<0.05$. The antioxidant activity of Maté infusions observed in different studies appeared important, regardless of the analytical methodology used or the origin of Maté. Knowing the quantitative and qualitative composition of the bioactive compounds present in the Maté drinks and education for its consumption could bring the benefits to the population (Bastos and Torres 2003). The best product should be defined through the sensory tests, associated to process conditions.

Table 6 - Matrix of $2^{2}$ experimental design $2^{2}$ (real and coded values) with the response to antioxidant capacity in oxidized leaves from Maté.

\begin{tabular}{lccccc}
\hline \multirow{2}{*}{ Runs } & \multicolumn{2}{c}{ Variables } & \multicolumn{3}{c}{ Antioxidant capacity (\%) } \\
\cline { 2 - 6 } & $\mathbf{X}_{\mathbf{1}}$ & $\mathbf{X}_{\mathbf{2}}$ & $\mathbf{1}$ min & $\mathbf{1 0}$ min & $\mathbf{2 0 ~ m i n}$ \\
\hline 1 & $-1(80)$ & $1(12)$ & 61.31 & 81.69 & 78.02 \\
2 & $1(99)$ & $1(12)$ & 93.16 & 94.33 & 94.66 \\
3 & $0(90)$ & $1(12)$ & 68.11 & 79.32 & 76.98 \\
4 & $-1(80)$ & $-1(1)$ & 68.81 & 61.64 & 72.72 \\
5 & $1(99)$ & $-1(1)$ & 58.87 & 82.59 & 75.92 \\
6 & $0(90)$ & $-1(1)$ & 66.88 & 108.57 & 83.29 \\
7 & $1(99)$ & $0(6.5)$ & 72.11 & 79.45 & 73.68 \\
8 & $-1(80)$ & $0(6.5)$ & 81.35 & 93.76 & 92.06 \\
9 & $0(90)$ & $0(6.5)$ & 48.17 & 86.59 & 66.41 \\
10 & $0(90)$ & $0(6.5)$ & 48.18 & 86.58 & 66.45 \\
11 & $0(90)$ & $0(6.5)$ & 48.15 & 86.59 & 66.39 \\
\hline
\end{tabular}

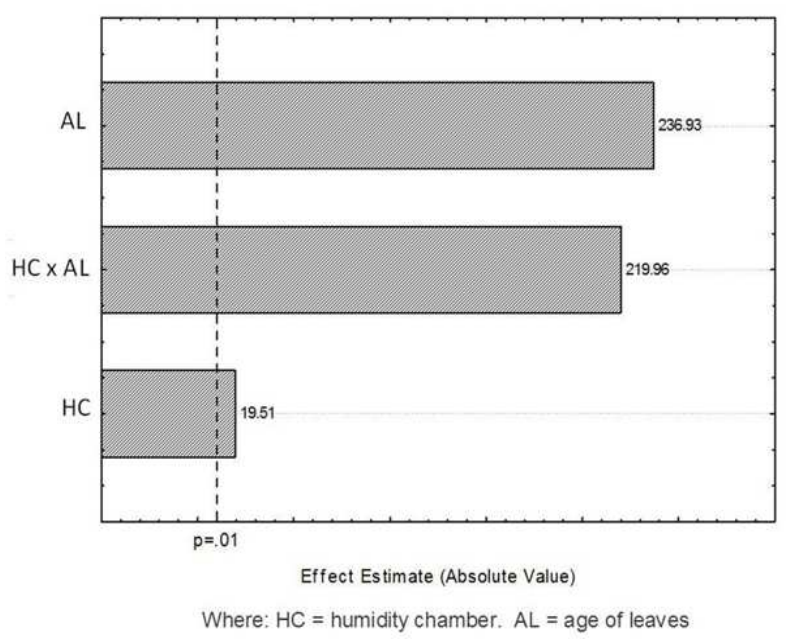

Figure 4 - Pareto chart of effects of the studies factors on the antioxidant capacity. $\mathrm{HC}=$ humidity of chamber $(\%) ; \mathrm{AL}=$ Age of leaves (months).

\section{CONCLUSION}

The air humidity of the chamber and leaf age influenced the oxidation process the leaves of
Maté as well as the antioxidant capacity of the extract obtained. Intermediate air humidity content of the chamber resulted in higher values of $a_{w}$ after the oxidation process. Only the chamber humidity affected the contents of phenolics in the extracts, and young leaves showed more intense brown color than the matured leaves.

\section{REFERENCES}

Assolini FA, Tedesco AM, Carpes ST, Ferraz C, Alencar SM. Antioxidant and antibacterial activities of phenolic compounds from extracts of plants used as tea. Braz Arch Biol Technol. 2006; 49(2): 209-215.

Bastos DHM, Torres EAFS. Maté (Ilex paraguariensis) beverages and public health. J Braz. Soc Food and Nutrition. 2003; 26: 77-89.

Bastos DHM, Fornari AC, Queiroz YS, Torres EAFS. Bioactive compounds content of Chimarrao infusions related to the moisture of yerba mate (Ilex paraguariensis) leaves. Braz Arch Biol Technol. 2006; 49(3): 399-404.

Bastos DHM, Saldanha LA, Catharino RR, Sawaya AS, Cunha IB, Carvalho PO, et al. Phenolic antioxidants identified by ESI-MS from Yerba Mate (Ilex paraguariensis) and green tea (Camelia sinensis) extracts. Molecules. 2007; 12(3): 423-432.

Bracesco N, Dell M, Rocha A, Behtash S, Menini T, Gugliucci C, et al. Antioxidant activity of a botanical extract preparation of Ilex paraguariensis: Prevention of DNA double-strand breaks in Saccharomyces cerevisiae and human low-density lipoprotein oxidation. J Altern Complement Med. 2003; 9(3): 379-387.

Brand-Williams W, Cuvier ME, Berset C. Use of a free radical method to evaluate antioxidant activity. Lebensmittel-Wissenschaft Technol. 1995; 28(1): 2530.

Bravo L, Goya L, Lecumberri E. LC/MS characterization of phenolic constituents of Mate (Ilex paraguariensis, St. Hil.) and its antioxidant activity compared to commonly consumed beverages. Food Res Int. 2007; 40(3): 393-405.

Chandra S, Mejia EG. Polyphenolic compounds, antioxidant capacity, and quinone reductase activity of na aqueous extracts of Ardisia compressa in comparison to mate (Ilex paraguariensis) and green (Camellia sinensis) teas. J Agric Food Chem. 2004; 52(11): 3583-3590.

Colpo G, Trevisol L, Teixeira AM, Fachinetto R, Pereira RP, Athayde ML, et al. Ilex paraguariensis has antioxidant potential and attenuates haloperidolinduced orofacial dyskinesia and memory dysfunction in rats. Neurotox Res. 2007; 12(3):171180. 
Conde E, Cadahía E, Garcia-Vallejo MC, Simón BF. Polyphenolic composition of Quercus suber cork from different spanish provenances. J Agric Food Chem. 1998; 46(8): 3166-3171.

Deladino L, Anbinder PS, Navarro AS, Martino MN. Encapsulation of natural antioxidants extracted from Ilex paraguariensis. Carbohydr Polym. 2007; 71(1): 126-134.

Filip R, Lopez P, Giberti G, Coussio J, Ferraro G. Phenolic compounds in seven South American Ilex species. Fitoterapia. 2001; 72(7): 774-778.

Filip R, Sebastian T, Ferraro G, Anesini C. Effect of Ilex extracts and isolated compounds on peroxidase secretion of rat submandibulary glands. Food Chem Toxicol. 2007; 45(4): 649-655.

Kolakowska A, Frankel E. Lipid oxidation in food systems. Dundee U. K, 1998.

Lanzetti M, Bezerra FS, Romana-Souza B, BrandoLima AC, Koatz VL, Porto LC, et al. Mate tea reduced acute lung inflammation in mice exposed to cigarette smoke. Nutrition. 2008; 24(4): 375-381.

Lunceford N, Gugliucci A. Ilex paraguariensis extracts inhibit AGE formation more efficiently than green tea. Fitoterapia. 2005; 76(5): 419-427.

Melo EC, Radünz LL, Melo RCM. Influence of the Drying Process on the Quality of Medicinal Plants Revision. Eng Agricul. 2004; 12(4): 307-315.

Mejía EG, Song YS, Heck CI, Ramírez-Mares MV. Yerba mate tea (Ilex paraguariensis): Phenolics, antioxidant capacity and in vitro inhibition of colon cancer cell proliferation. J Functional Foods. 2010; 2(1): 23-34.

Menini T, Heck C, Schulze J, Gonzalez de Mejia E, Gugliucci A. Protective action of Ilex paraguariensis extract against free radical inactivation of paraoxonzae-1 in high density lipoprotein. Planta Med. 2007; 73(11): 1141-1147.

Miranda DD, Açari DP, Pedrazzoli J, Carvalho PO, Cerutti SM, Bastos DH, et al. Protective effects of mate tea (Ilex paraguariensis) on $\mathrm{H}_{2} \mathrm{O}_{2}$-induced DNA damage and DNA repair in mice. Mutagenesis. 2008; 23(4): 261-265.
Molin RF, Valduga AT, Di Luccio M, Dartora N, Cichoski AJ, Pistore $\mathrm{M}$, et al. Assessment of oxidation of leaves of Ilex paraguariensis (St. Hil). Braz Arch Biol Technol. 2011; 54(2): 337-345.

Moure A, Cruz JM, Franco D, Domínguez JM, Sineiro $\mathrm{J}$, Domínguez $\mathrm{H}$, et al. Natural antioxidants from residual sources. Food Chem. 2001; 72(2): 145-171.

Muthumani T, Kumar RSS. Influence of fermentation time on the development of compounds responsible for quality in black tea. Food Chem. 2007; 101(1): 98-102.

Obanda M, Owuor O, Mangoka R. Changes in the chemical and sensory quality parameters of black tea due to variations of fermentation time and temperature. Food Chem. 2001; 75(4): 395-404.

Pomilio AB, Trajtemberg S, Vitale AA. Highperformance capillary electrophoresis analysis ofMate infusions prepared from stems and leaves of Ilex paraguariensis using automated micellar electrokinetic capillary chromatography. Phytochem Anal. 2002; 13(4): 235-241.

Saldanha L. In vitro antioxidant activity of extracts of green and roasted mate (Ilex paraguariensis) and green tea (Camellia sinensis). [dissertation], São Paulo, Brazil: Universidade de São Paulo; 2005.

Turkmen N, Sari F, Velioglu S. Effects of extraction solvents on concentration and antioxidant activity of black and black mate tea polyphenols determined by ferrous tartrate and Folin-Ciocalteu methods. Food Chem. 2006; 99(4): 835-841.

Vanderjagt TJ, Ghattas R, Vanderjagt DJ, Crossey M, Glew RH. Comparison of the total antioxidant contend pf 30 widely used medicinal plants of New Mexico. Life Sci. 2002; 70(9): 1032-1040.

Zaporozhets OA, Krushynska OA, Lipkovska NA, Barvinchenk VN. A new test method for the evaluation of total antioxidant activity of herbal products. J Agric Food Chem. 2004; 52(1): 21-25.

Received: August 21, 2013; Accepted: July 10, 2014. 